\title{
STUDY OF PREVALENCE OF VARIOUS DISORDERS AND PRESENTING COMPLAINTS IN PATIENTS OF VAGINAL DISCHARGE
}

Bhawna Kapoor ${ }^{1}$, Ankit Kapoor ${ }^{2}$, Samir Shah ${ }^{3}$, Nitin Vora $^{4}$

${ }^{1}$ Assistant Professor, Dept. of Skin \& V. D, Mayo Institute of Medical Sciences, Safedabad, Barabanki, Uttar Pradesh. ${ }^{2}$ Assistant Professor, Dept. of Skin \& V. D, Mayo Institute of Medical Sciences, Safedabad, Barabanki, Uttar Pradesh. ${ }^{3}$ Deputy Director ESIS, Gujarat, Former Professor \& PG Guide, Dept. of Skin \& V.D, General Hospital Bapunagar, E.S.I. Scheme, C/o. B. J. Medical College, Civil Hospital, Ahmedabad, Gujarat.

${ }^{4}$ Dean, GMERS Medical College \& Hospital, Sola, Ahmedabad, Former HOD Professor \& PG Guide, Dept. of Skin \& V.D, General Hospital, Bapunagar, E.S.I. Scheme, C/o. B. J. Medical College, Civil Hospital, Ahmedabad, Gujarat.

\section{ABSTRACT}

\section{BACKGROUND}

VD is considered as Abnormal Vaginal Discharge (AVD) when it is either a hypervaginal secretion not associated with menstruation or offensive/malodorous discharge or yellowish discharge. The various causes of AVD can be broadly divided into physiological and pathological.

\section{AIMS}

The aim of this study to know the various symptoms in patients of Vaginal Discharge. Study also aimed to know the prevalence of various aetiologies causing Vaginal Discharge.

\section{SETTING AND DESIGN}

Present study comprised of 150 patients attending STD clinic with complains of vaginal discharge.

\section{METHODS AND MATERIALS}

Detailed history of all patients, symptoms associated with them and h/o of spouse/partner. Appropriate tests were done to diagnose various infective aetiologies.

\section{RESULTS}

Pruritus (51.33\%) was present as the most common complain followed by urinary complaints (37\%). Bacterial vaginosis (42\%) was seen in maximum patients followed by Vaginal candidiasis (24\%).

\section{CONCLUSION}

Vaginal discharge is a common inherent complains in females. Because of their inherent biological vulnerability for RTI/STI all females must 31 be screened periodically for the evidence of genital tract involvement, so that they can promptly and effectively treated. In time management of vaginal discharge not only prevents spread of disease, minimizes/prevents complications (Like PID, Female Infertility) 16, brings down the high expenses involved in treating them and possibly also the HIV transmission.

\section{KEYWORDS}

Vaginal Discharge, Presenting Complaints, Bacterial Vaginosis, Pruritus.

HOW TO CITE THIS ARTICLE: Kapoor B, Kapoor A, Shah S, et al. Study of prevalence of various disorders and presenting complaints in patients of vaginal discharge. J Evolution Med Dent Sci 2016;5(1):87-91, DOI: 10.14260/jemds/2016/20

\section{INTRODUCTION}

VD is considered as Abnormal Vaginal Discharge (AVD) when it is either a hypervaginal secretion not associated with menstruation or offensive/malodorous discharge or yellowish discharge. ${ }^{1}$ The various causes of AVD can be broadly divided into physiological and pathological. Identifying its source can be challenging, because a large number of pathogens cause vaginal and cervical infection, and several infections may coexist. $^{2}$

Financial or Other, Competing Interest: None.

Submission 16-12-2015, Peer Review 17-12-2015,

Acceptance 29-12-2015, Published 04-01-2016.

Corresponding Author:

Dr. Ankit Kapoor

4/491, Vivek Khand,

Gomti Nagar,

Lucknow-226010.

E-mail:drankitkapoor@gmail.com

DOI:10.14260/jemds/2016/20
Specific treatment for the vaginal discharge after identification of causative organism is time consuming, required skilled and well equipped laboratory set-up and costly, may not be possible in all set ups, so the treatment may be initiated based on clinical finding alone at times. Recently, careful definition of clinical syndromes and increased knowledge about the specific agents that cause genital infection in women have made more precise diagnosis possible. ${ }^{3}$

Present study was conducted in industrial population. The aim of this study to know the various symptoms in patients of Vaginal Discharge. Study also aimed to know the prevalence of various aetiologies causing Vaginal Discharge. General awareness about the STDs, condom usage, maintaining hygiene and tendency to seek quality STD health care is generally lacking, in this group, especially in women.

\section{METHOD}

Present study comprised of 150 women attending the STD clinic with chief complains of symptomatic vaginal discharge. 
Detailed history of all patients, including the H/o present and past illness, treatment taken, obstetric and menstrual history, history of contraceptive method used, personal history and hygiene, history regarding sexual behaviour, H/o spouse/partner having genital complaints/discharge were also taken and recorded.

After making the clinical diagnosis, appropriate tests for diagnosing candidiasis, trichomoniasis, gonorrhoea, chlamydia and bacterial vaginosis were done. Amsel's criteria was used for diagnosing Bacterial Vaginosis.

Women who were in menstrual phase or had received any treatment for discharge in preceding six weeks were not included in present study. Unmarried females and patients having discharge due to the gynaecological conditions such as fistulae, tumours, radiation effects, postoperative were also not included.

Local examination to see for any discharge, oedema, ulceration, erosion, growth or any other lesions and hygiene was done. Presence of any pain, tenderness or restricted cervical movement was also looked for. Warm water was used to provide sufficient lubrication for the speculum insertion in each patient.

The amount, source, color, consistency and odor of the vaginal discharge were noted. Cervical mobility was also noted. Swabs were subjected to following/various tests and slide preparations. Wet film (Amine/Whiff test) and $10 \% \mathrm{KOH}$ preparation examined immediately under microscope. Gram stain, Tzanck smear and cultures were also done as and when indicated.

In case of VVC culture was only done when smear studies were negative and signs and symptoms were suggestive of VVC. Similarly N. gonorrhoeae were diagnosed on the basis of the gram stain of urethral and vaginal discharge. Demonstration of intracellular diplococci at least three pairs or more is strongly suggestive of the $\mathrm{N}$ gonorrhoeae. ${ }^{1}$

Culture on Modified Thayer Martin media was done in required cases. Chlamydia trachomatis has iodine staining inclusions, their diagnosis was based on presence of these inclusion bodies. However, it is noted that swabs taken from the endocervix and patients having mucopurulent discharge were subjected to diagnosis of Chlamydia trachomatis. ${ }^{4}$ and $\mathrm{N}$. gonorrhoeae. ${ }^{5}$

\section{RESULTS}

Youngest patient in the study was 19 yrs old and was diagnosed as Trichomoniasis and eldest patient, 52 yrs old was having candidiasis. Maximum patients were from 26-35 years age group. Table No. 1 shows that maximum no. patients in present study were having bacterial vaginosis (42\%) followed by candidiasis $(24 \%)$ and Trichomoniasis $(10 \%)$. In Table No. 1 'Others' include 4 patients of non-specific vaginitis, where $\mathrm{E}$. coli and Klebsiella were found on culture and 8 patients in which no organism was detected.

Patients presented with varying complaints in present study. Table No. 2 shows details of frequency of each complaint. Total of 4 patients of diabetes mellitus were seen in present study and all were having VVC. One patient aged 32 yrs was HIV positive, who had both VVC and TV. Another patient had history of recurrent abortions, was TORCH positive (IgG and IgM for HSV1 and 2) also had TV. Table No. 3 shows the comparison of symptoms in various disorders.
Maximum patients of VVC had good hygiene (83.33\%). TV had most patients in poor hygiene $(80.00 \%)$ category.

\section{DISCUSSION}

Present study of 150 patient unfolded several multifaceted factors which may be directly or indirectly involved in acquiring the disorders. Pruritus in present study was the commonest complaint was seen in $51.33 \%$ of the patients is comparable with studies of KJPS Puri et al. ${ }^{3}$ (49\%) and V. Gupta. ${ }^{6}$ et al. (43.9\%).

Lack of cleanliness, acidic discharge and diabetes could be the cause for pruritus in VD. ${ }^{7}$ Urinary complaint (Dysuria and frequency of micturition) in patients of vaginal discharge was $37 \%$ as seen by KJPS Puri et al. ${ }^{3}$ while in present study it was $31.99 \%$. Backache was seen in present study in $6.66 \%$ of patients.

Causes of backache are many like uterine displacement/prolapse, endometriosis, osteoporosis, chronic pelvic infection, menstrual pain, in last weeks of pregnancy, postural back pain, trauma, sprain and strain, stress, lumbar disc disease, over exertion, age related, etc. In study by V. Gupta. ${ }^{6}$ et al. backache was seen in $59.9 \%$ of patients. V. Gupta. ${ }^{6}$ et al. observed lower abdominal Pain in $60.4 \%$ patients in contrast to $8.66 \%$ patients in present study.

This difference could be explained because of the lesser number of Chlamydia (3.3\%) and gonorrhoea (8\%), Trichomoniasis $(10 \%)$ patients found in our study. These disorders can cause acute salpingitis. ${ }^{8,4,9}$ which presents with lower abdominal pain. Dyspareunia which was seen in $16.66 \%$ of patients in present study is comparable with that of by $\mathrm{V}$. Gupta. ${ }^{6}$ et al. (15.1\%).

Table No. 4 shows the comparison of Incidence of various causes of vaginal discharge in different studies. Present study showed a maximum incidence of Bacterial Vaginosis (42\%).

This is in accordance with findings of KJPS Puri et al. ${ }^{3}$ (45\%) and V. Gupta. ${ }^{6}$ et al. (44.6\%). The incidence of bacterial vaginosis is also comparable to that of Mahadani et al.10 (44.30\%), Kamara P et al. ${ }^{11}$ (44.10\%). Whiff test was positive in $47.6 \%$ and in microscopic result, CLUE cells were seen in the $82.5 \%$ of patients of Bacterial Vaginosis.

Results of study are comparable to study conducted on 661 randomly selected women attending a STD clinic. ${ }^{12}$ where whiff test was positive in $43 \%$ and CLUE cells were seen in the $78.0 \%$ of patients. The principal benefits of diagnosing bacterial vaginosis is not only relief of symptoms of these conditions, thereby meeting a major expectation of clients, as well as the prevention of gynaecological. ${ }^{7}$ and obstetric complications. ${ }^{5}$ (And possibly HIV transmission) associated with bacterial vaginosis.

Incidence of VVC varied from findings of V. Gupta. ${ }^{6}$ et al. (9.3\%) and Mahadani et al. ${ }^{10}(9.49 \%)$ to that of KJPS Puri et al. ${ }^{3}$ (31\%) and Levett PN. ${ }^{13}$ (44\%). In present study it was $24 \%$. The incidence can also be comparable to that of Ries AJ.14 (20$25 \%)$ and Kamara P et al. ${ }^{11}$ (30.7\%). In study of V. Acharya et al. 15 it was $18.863 \%$.

Though the results of present study were not comparable to V. Gupta. ${ }^{6}$ et al. (9.3\%), Fonck et al. ${ }^{16}$ (9.0\%) and Mahadani et al. ${ }^{10}$ (9.49\%), but all of them had VVC as most common infection after bacterial vaginosis. In VVC patients usually present with acute pruritus. ${ }^{1}$ curdy, white. ${ }^{17}$ scanty to moderate, ${ }^{18}$ discharge. Similar was found in our study where 
patients of VVC were having pruritus (86.11\%), curdy (75\%), white $(86.11 \%)$ mild (83.33\%) discharge.

Trichomoniasis was seen in $10 \%$ of patients in present study, which is in accordance with that V. Gupta. ${ }^{6}$ (7.9\%), V. Acharya et al. ${ }^{15}$ (11.32\%), Ries AJ.14 (10\%) and Levett PN. ${ }^{13}$ (8.6\%). The poor local hygienic condition, colonization of the Candida and anaemia helps in colonization and multiplication of T. vaginalis. ${ }^{19}$

Incidence of trichomoniasis has decreased in recent years. Natarajan et $a .^{20}$ observed a changing profile of vaginal Trichomoniasis by diminishing trend of acute symptoms and increasing trend of asymptomatic status. ${ }^{3}$

It was observed that increasingly wide use drugs like metronidazole for gynaecological and non-gynaecological indications should be contributing to this changing profile of trichomonial infection. ${ }^{3}$ Presenting complaints and character of VD in patients of trichomoniasis can be compared favourably with findings of Hiene P et al. ${ }^{21}$ (Pruritus (23-82\%), malodour (50-75\%), dysuria (30-50\%), dyspareunia (10$50 \%)$.

Abdominal pain, described in up to $12 \%$ of women. ${ }^{22,23}$ may be because of severe vaginitis, regional lymphadenopathy, or conceivably endometritis or salpingitis due to T. vaginalis or another concurrent infection. ${ }^{9}$ Pain in abdomen was present in $13.33 \%$ of patients in our study.

The incidence of Gonorrhoea (8\%) in our study is analogous with findings of V. Acharya et al. ${ }^{15}$ (8.93\%), Fonck et al. ${ }^{16}(7.0 \%)$ and Alary $\mathrm{M}$ et al. ${ }^{24}$ (5.7\%). The incidence of Chlamydia in present study was $3.33 \%$ is comparable to the findings of Alary M et al. ${ }^{24}$ (2.1\%) and Costello Daly C. ${ }^{25}$ et al (3.7\%).

Diagnosis of Chlamydia was done clinically and on presence of inclusion bodies on swab from cervical smears. Mixed Infection was seen in $4.66 \%$ of patients in present study. Multiple organism in the same patient have been reported earlier also by Joshi et al. ${ }^{26}$ Bandi et al. ${ }^{27}$ in their respective studies. Non-specific vaginitis was seen in only $4(2.66 \%)$ patients in present study.

After going through Table No. 6 it seems that incidence of most of disorders vary considerably. They differ from place to place, time to time, rural to urban, from one society to another and age group of the patient included in the study.

Following factors like Socioeconomic status, Diabetes Mellitus, sexual activity, personal hygiene, poor utilization of health services by young married women, methods of contraception used, co-existent infection also result in varied incidences of above disorders.

\section{CONCLUSION}

Because of their inherent biological vulnerability for RTI/STI all females must. ${ }^{28}$ be screened periodically for the evidence of genital tract involvement so that they can promptly and effectively treated. Prevalence of these disorders is influenced by several multifaceted factors which may be directly or indirectly involved in acquiring the disorders.

Most of these women are young, indigent and faced with social challenges that often pose more of an immediate threat to their well-being. ${ }^{28}$ A Good number of cases do not seek treatment either due to the fear of guilt or because they are a

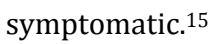

In time management of vaginal discharge not only prevents spread of disease, minimizes/prevents complications (Like PID, Female Infertility). ${ }^{15}$ brings down the high expenses involved in treating them and possibly also the HIV transmission.

Because of the relatively trivial nature of VD, cost and time factor, lack of specialized instruments and skilled man power, treatment may be initiated based on clinical finding alone at times. However, the common aetiological agents of vaginal discharge respond to specific therapies and their symptoms are sufficiently similar to render clinical diagnosis difficult. Therefore, laboratory investigations are appropriate.

\begin{tabular}{|c|c|c|c|}
\hline $\begin{array}{l}\text { SL. } \\
\text { No. }\end{array}$ & Disorder & $\begin{array}{c}\text { No. of } \\
\text { pts. }\end{array}$ & Percentage \\
\hline 1. & Bacterial Vaginosis & 63 & 42 \\
\hline 2. & Vaginal Candidiasis & 36 & 24 \\
\hline 3 & Trichomoniasis & 15 & 10 \\
\hline 4. & Gonococcal cervicitis & 12 & 8 \\
\hline 5 & Chlamydial cervicitis & 05 & 3.33 \\
\hline 6. & Mixed infection & 07 & 4.66 \\
\hline 7. & Others & 12 & 8.00 \\
\hline & Total & 150 & 100.00 \\
\hline
\end{tabular}

\begin{tabular}{|c|c|c|c|}
\hline No. & Symptoms & No. & Percentage \\
\hline 1. & Pruritus & 77 & 51.33 \\
\hline 2. & Mal odour & 71 & 47.32 \\
\hline 3. & Dysuria & 31 & 20.66 \\
\hline 4. & Dyspareunia & 25 & 16.66 \\
\hline 5. & $\begin{array}{c}\text { Frequency of } \\
\text { micturition }\end{array}$ & 17 & 11.33 \\
\hline 6. & Pain in lower abdomen & 13 & 8.66 \\
\hline 7. & Low backache & 10 & 6.66 \\
\hline 8. & Genital lesions & 4 & 2.66 \\
\hline \multicolumn{3}{|c|}{ Table 2: Details of frequency of each complaint in total } \\
Pt. of Vaginal Discharge \\
\hline
\end{tabular}




\begin{tabular}{|c|c|c|c|c|c|c|c|}
\hline DISORDER & VVC & TV & BV & GC & CC & MXD & OTH \\
\hline $\mathrm{n}$ & $n=36$ & $n=15$ & $n=63$ & $\mathrm{n}=12$ & $n=5$ & $n=7$ & $n=12$ \\
\hline $\begin{array}{l}\text { Pruritus } \\
(n=77)\end{array}$ & $\begin{array}{c}31 \\
(86.11 \%)\end{array}$ & $\begin{array}{c}11 \\
(73.33 \%)\end{array}$ & $\begin{array}{c}16 \\
(25.39 \%)\end{array}$ & $\begin{array}{c}2 \\
(16.6 \%)\end{array}$ & $\begin{array}{c}1 \\
(20 \%)\end{array}$ & $\begin{array}{c}7 \\
(100 \%)\end{array}$ & $\begin{array}{c}9 \\
(75 \%)\end{array}$ \\
\hline $\begin{array}{l}\text { Mal odour } \\
(n=71)\end{array}$ & $\begin{array}{c}9 \\
(25.00 \%)\end{array}$ & $\begin{array}{c}10 \\
(66.66 \%)\end{array}$ & $\begin{array}{c}49 \\
(77.77 \%)\end{array}$ & 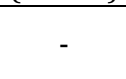 & - & $\begin{array}{c}2 \\
(28.6 \%)\end{array}$ & $\begin{array}{c}1 \\
(8.3 \%)\end{array}$ \\
\hline $\begin{array}{c}\text { Dysuria } \\
(\mathrm{n}=31)\end{array}$ & $\begin{array}{c}9 \\
(25.00 \%) \\
\end{array}$ & $\begin{array}{c}7 \\
(46.66 \%) \\
\end{array}$ & $\begin{array}{c}1 \\
(1.57 \%) \\
\end{array}$ & $\begin{array}{c}10 \\
(83.6 \%) \\
\end{array}$ & $\begin{array}{c}2 \\
(40 \%) \\
\end{array}$ & $\begin{array}{c}1 \\
(14.2 \%) \\
\end{array}$ & $\begin{array}{c}1 \\
(8.3 \%) \\
\end{array}$ \\
\hline $\begin{array}{l}\text { Dyspareunia } \\
(\mathrm{n}=25)\end{array}$ & $\begin{array}{c}6 \\
(16.66 \%)\end{array}$ & $\begin{array}{c}7 \\
(46.66 \%)\end{array}$ & $\begin{array}{c}7 \\
(11.11 \%)\end{array}$ & $\begin{array}{c}3 \\
(25.0 \%)\end{array}$ & $\begin{array}{c}1 \\
(20 \%)\end{array}$ & 1 & $(0,0)$ \\
\hline $\begin{array}{l}\text { Frequency of } \\
\text { micturition } \\
(n=17)\end{array}$ & $\begin{array}{c}7 \\
(19.44 \%)\end{array}$ & $\begin{array}{c}2 \\
(13.33 \%)\end{array}$ & $\begin{array}{c}1 \\
(1.57 \%)\end{array}$ & $\begin{array}{c}2 \\
(16.6 \%)\end{array}$ & $\begin{array}{c}1 \\
(20 \%)\end{array}$ & $\begin{array}{c}3 \\
(42.8 \%)\end{array}$ & $\begin{array}{c}1 \\
(8.3 \%)\end{array}$ \\
\hline $\begin{array}{l}\text { Pain in } \\
\text { lower abd } \\
(n=13)\end{array}$ & - & $\begin{array}{c}2 \\
(13.33 \%)\end{array}$ & $\begin{array}{c}6 \\
(9.52 \%)\end{array}$ & 2 & - & $\begin{array}{c}1 \\
(14.2 \%)\end{array}$ & $\begin{array}{c}3 \\
(25 \%)\end{array}$ \\
\hline $\begin{array}{c}\text { Low backache } \\
(\mathrm{n}=10)\end{array}$ & - & $\begin{array}{c}2 \\
(13.33 \%) \\
\end{array}$ & $\begin{array}{c}4 \\
(6.34 \%) \\
\end{array}$ & 2 & & $\begin{array}{c}1 \\
(14.2 \%) \\
\end{array}$ & $\begin{array}{c}1 \\
(8.3 \%) \\
\end{array}$ \\
\hline $\begin{array}{l}\text { Cervical lesions } \\
(\mathrm{n}=4)\end{array}$ & - & $\begin{array}{c}1 \\
(6.66 \%)\end{array}$ & - & 2 & 1 & - & - \\
\hline
\end{tabular}

(MXD=MIXED: OTH=OTHERS WHICH INCLUDE NONSPECIFIC VAGINITIS AND GROUP WHERE NO ORGANISM COULD BE CULTURED. TV =VAGINITIS CAUSED BY TRICHOMONIAS)

\begin{tabular}{|c|c|c|c|c|c|c|}
\hline Sl. No. & Study & BV & VVC & TV & GC & Others \\
\hline 1. & $\begin{array}{l}\text { V Acharya. }{ }^{15} \\
\text { et al. }\end{array}$ & $24.90 \%$ & $18.86 \%$ & $11.32 \%$ & $8.93 \%$ & $32.71 \%$ \\
\hline 2. & V. Gupta. ${ }^{6}$ et al. & $44.6 \%$ & $9.3 \%$ & $7.9 \%$ & 0 & - \\
\hline 3. & Kamara P11 et al. & $44.10 \%$ & $30.7 \%$ & $18 \%$ & - & - \\
\hline 4. & Fonck et al. ${ }^{16}$ & $50 \%$ & $9 \%$ & $23 \%$ & $7 \%$ & $\begin{array}{l}9 \% \text { Chlamydia, } \\
22 \% \text { HIV }\end{array}$ \\
\hline 5. & Costello Daly C..$^{25}$ et al. & - & - & - & $17.1 \%$ & 3.7\%,Chlamydia \\
\hline 6. & Alary M. ${ }^{24}$ et al. & - & - & - & $5.7 \%$ & 2.1\%, Chlamydia \\
\hline 7. & KJPS Puri et al. ${ }^{3}$ & $45 \%$ & $31 \%$ & $2 \%$ & $3 \%$ & $5 \%(\mathrm{NS})$ \\
\hline 8. & Mahadani et al. ${ }^{10}$ & $44.30 \%$ & $9.49 \%$ & $16.45 \%$ & $0.63 \%$ & $12 \%$ Cases (Senile) \\
\hline 9. & Ries AJ.14 & $30-35 \%$ & $20-25 \%$ & $10 \%$ & - & $15-20 \%$ Cases (Mixed) \\
\hline 10. & Levett PN.13 & $28 \%$ & $44.6 \%$ & $8.6 \%$ & - & $10 \%$ Cases (Mixed) \\
\hline 11. & $\begin{array}{l}\text { Present } \\
\text { Study }\end{array}$ & $42 \%$ & $24 \%$ & $10 \%$ & $8 \%$ & $\begin{array}{l}4.66 \% \text { Cases } \\
\text { (mixed) }\end{array}$ \\
\hline
\end{tabular}

\section{REFERENCES}

1. Kanwar AJ; Clinical approach to vaginal/urethral discharge: in sexually transmitted disease and AIDS, VK Sharma: Printed at New Delhi: 2003, Viva Publishers: 1st edition; Chpt 43, Pg 463-470.

2. Fox KK, Behets FM. Vaginal discharge. How to pinpoint the cause. Postgraduate Medicine 1995;98:87-90, 93-96, 101. In IJDVL Volume 69; 2003: Issue 2, pg122-125.

3. KJPS Puri, Anita M, Kiran B: Incidence of various causes of vaginal discharge amongst sexually active females in age group 20-40 yrs: IJDVL 2003; Vol 69, Issue 2, pg 122125.

4. Sabyasachi Majumdar, Saha GC; chlamydia infections and non gonococcal urethritis: in sexually transmitted disease and AIDS, Sharma VK: New Delhi: 2003, Viva Publishers: 1st edition; Chpt 21, Pg 234-244.

5. Venkateswaram K, Mohan S; Gonorrhoea: in sexually transmitted disease and AIDS, Sharma VK: New Delhi: 2003, Viva Publishers: 1st edition; Chpt 20, Pg 226-229.
6. Gupta V, Biswaroop C, Devender P, Renu D, et al. Clinical spectrum and microbial etiology of reproductive tract infections in rural women in the hills of North India; In J of Obs \& Gyn of India Vol 52, No. 1: Jan/Feb 2002, pg 130-134.

7. The practice of gynecology, by John Wesley Bovée in English; Published by Philadelphia and New York, Lea brothers \& co. 1906; Digitized 16 March 2006. OCLC: 14806325 : Link to this Page: http://worldcat.org/oclc/14806325.

8. Edward W Hook III, H Hunter Handsfield; Gonococcal infections in adult: in sexually transmitted diseases, 3rd edition Holmes KK, Mardh PA, Sparling PF, et al. (Eds.), 1999, New York, McGraw Hill; Chapter 32, pg 451-464.

9. John N Krieger, John F Alderete: trichomonas vaginalis: in sexually transmitted diseases, 3rd edition, Holmes KK, Mardh PA, Sparling PF, et al. (Eds.), 1999, New York , McGraw Hill; Chapter 43, pg 587-603. 
10. Mahadani JW, Dekate RR, Shrikhande AV. Cytodiagnosis of discharge per vaginum: Indian J Pathol Microbiol 1998;41: pg 403-411: In IJDVL 2003; VOL 69, Issue 2, pg 122-125.

11. Kamara P, Kong TH, Brathwaite A, et al. Vaginal infections in pregnant women in Jamaica: prevalence and risk factors. Int STD and AIDS 2000; 11: pg 516-520. In IJDVL 2003; VOL 69, Issue 2, pg 122-125.

12. Sharon Hillier, King K Holmes: Bacterial vaginosis: in sexually transmitted diseases, 3rd edition, Holmes KK, Mardh PA, Sparling PF, et al. (Eds.), 1999, New York, McGraw Hill; Chapter 42, pg 568.

13. Levtt PN: Aetiology of vaginal infections in pregnant and non-pregnant women in Barbados. West Indian Med J: 1995;44:96-98: In IJDVL 2003; Vol 69, Issue 2, pg 122125.

14. Reis AJ. Treatment of vaginal infections: candidiasis, bacterial vaginosis and trichomoniasis. J Am Pharm Assoc (Wash) 1997; NS 37:Pg 563-569: IJDVL 2003; Vol 69, Issue 2, pg 122-125.

15. Acharya V, Mathur D, Jain P, et al. Sexually transmitted diseases in gynaecological practice: J of Obs \& Gyn, Vol. XXXVIII, June 1990-No. 3: pg 341-343.

16. Fonck K, Kidula N, Jaoko W, et al. Validity of the vaginal discharge algorithm among pregnant and non-pregnant women in Nairobi, Kenya. Sexually transmitted infection 2000;76: pg 33-38. IJDVL 2003; VOL 69, Issue 2, pg 122125.

17. Kanwar AJ, Mamta, Jagdish C; superficial fungal infections: in IADVL text book and atlas of dermatology; 2003, 2nd edition, Mumbai, Bhalani Publishing House, Chpt 12, pg 240.

18. Devinder M Thappa. Bacterial vaginosis: in sexually transmitted disease and AIDS, VK Sharma: New Delhi: 2003, Viva Publishers: 1st edition; Chpt 23, Pg 253-258.

19. Agrawal BM, Agrawal S, Singh PK, et al. Trichomonas vaginalis-an indicator for other sexually transmitted infecting agents. Indian J Dermatol Venereol Leprol 2000;66:241-243.
20. Natarajan S, Kumar P. Changing clinical profile of vaginal trichomoniasis. Obstet Gynaecol 1990; D 40: pg 809-811. In IJDVL 2003; Vol 69, Issue 2, pg 122-125.

21. Hiene P, MC Gregor JA: Trichomonas vaginalis: a reemerging pathogen, Clin Obstet Gynecol 1993;36:137 144. In: VK Sharma; Sexually transmitted disease and AIDS: 2003, New Delhi, Viva Books Private Limited, Chpt 28, pg 307-320.

22. Honiberg BM. Trichomods of importance in human medicine, in Parasitic Protozoa. JP Kreier (ed). New York, Academic Press, 1978, Vol, pg 275. In : Sexually transmitted diseases, 3rd edition, Holmes KK, Mardh PA, Sparling PF, et al. (eds.), 1999, New York, McGraw Hill; Chapter 43, pg 587-603.

23. Fouts AC, Kraus SJ: Trichomonas vaginalis; Re-evaluation of its clinical presentation and Lab. Diagnosis. J Inf Dis. 141:197, 1980. In: Sexually transmitted diseases, 3rd edition, Holmes KK, Mardh PA, Sparling PF, et al. (Eds.), 1999, New York, McGraw Hill; Chapter 43, pg 587-603.

24. Alary M, Bananizi E, Guedeme A, et al. Evaluation of clinical algorithms for diagnosis of gonococcal and chlamydial infections among men with urethral discharge or dysuria and women with vaginal discharge in Benin. Sex transm Infect 1998 June; 74 suppl 1: S4449.

25. Costello Daly C18 Wangel AM, Hoffman IF et al. Validation of the WHO diagnostic algorithm and development of an alternative scoring system for the management of women presenting with vaginal discharge. In Malawi. Sex Transm Infect 1998; 74 Suppl1:50-58.

26. Joshi J, Mali B, Hazari K, et al. J Obst Gyn India 41;521, 1991. In J of Obs \& Gyn of India Vol 52, No. 1: Jan/Feb 2002 pg 130-134.

27. Bandi S, Shridhar J, Dave A: J Obst Gyn India 48;48, 1998: I In J of Obs \& Gyn of India, Vol 52, No. 1: Jan/Feb 2002 pg130-134.

28. Marfatia YS, Archana Sharma, Divyesh Mistry, Indian J sex transmitted disease a clinico-epidemiological study of HIV in females, 2004; Vol 25 No 2, 74. 